\title{
Publications using the bayesv/ R package for Bayesian inference by 2022
}

\author{
Minh-Hoang Nguyen \\ Centre for Interdisciplinary Social Research \\ Phenikaa University
}

Yen Nghia, Ha Dong, Hanoi 100803, Vietnam

February 05, 2022
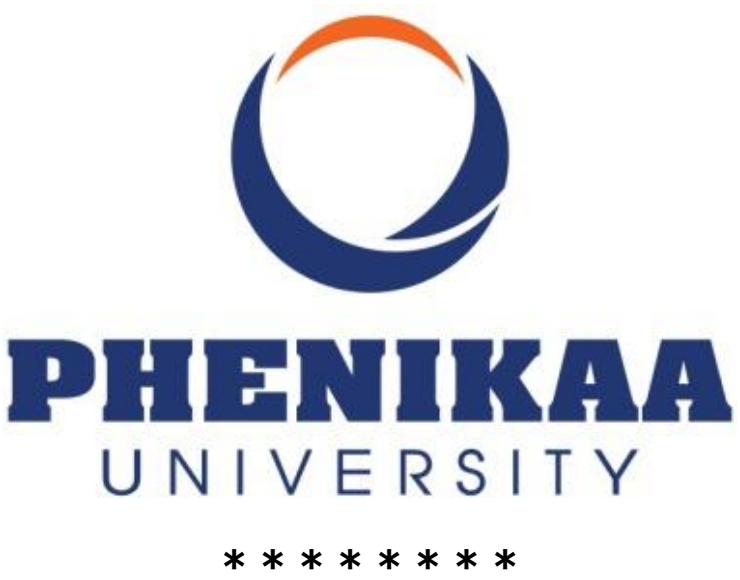

At around the same time last year, I summarized ISR's publications using the bayesv/R package for Bayesian inference [1]. This short note's purpose is also similar, and it is dedicated to tracking the package's contribution progress by summarizing the publications using the bayesv/R package [2]. The examined range is wider but not limited to the publications written by ISR.

By today, 27 publications ( 25 research articles and two books) have been published using the bayesv/ R package [3-29]. Such publications' scopes are diverse, ranging from sociology and psychology to scientific publishing and technology. Many are published by prestigious journals, like Humanities and Social Sciences Communications, Learned Publishing, Research Evaluation, Pacific Conservation Biology, Children and Youth Services Review, Sustainability, AI \& Society, etc. Out of 28 publications, two papers are written to demonstrate the package's usage protocol $[7,9]$. The protocol is also clarified in a Vietnamese book titled "Bản hòa tấu dữ liệu xã hội" [19].

Besides these publications, many other manuscripts under review and consideration also employ the bayesv/package for statistical analysis. Thus, I hope the bayesv/package can be capitalized more in order to contribute to scientific progress in 2022. 


\section{References}

1. Nguyen MH. (2021). The bayesvl R package and ISR's publications using Bayesian inference. OSF Preprints. Retrieved from: https://osf.io/rx3c6/

2. La VP, Vuong QH. (2019). Package 'bayesvl': Visually Learning the Graphical Structure of Bayesian Networks and Performing MCMC with 'Stan'. The Comprehensive R Archive Network (CRAN).

3. Vuong QH, Bui QK, La VP, Vuong TT, Ho TM, Nguyen HKT, Nguyen NH, Nghiem PKC, Ho MT. (2019). Cultural evolution in Vietnam's early 20th century: a Bayesian networks analysis of Hanoi Franco-Chinese house designs. Social Sciences \& Humanities Open, 1(1), 100001.

4. Le $A V$, Do DL, Pham DQ, Hoang PH, Duong $T H$, Nguyen HN, Vuong $T T$, Nguyen HKT, Ho MT, La VP, Vuong QH. (2019). Exploration of youth's digital competencies: a dataset in the educational context of Vietnam. Data, 4(2), 69.

5. Ho MT, La VP, Nguyen MH, Vuong TT, Nghiem KCP, Tran T, Nguyen HKT, Vuong $\mathrm{QH}$. (2019). Health care, medical insurance, and economic destitution: A dataset of 1,042 stories. Data, 4(2), 57.

6. Vuong $\mathrm{QH}$, Nguyen HKT, Ho MT, La VP, Vuong TT, Tran $T$, Hoang KL, Vu TH, Hoang PH, Nguyen MH, Ho MT. (2020). On how religions could accidentally incite lies and violence: Folktales as a cultural transmitter. Palgrave Communications, $6,82$.

7. Vuong QH, La VP, Nguyen MH, Ho MT, Ho MT, Mantello P. (2020). Improving Bayesian statistics understanding in the age of Big Data with the bayesvl $\mathrm{R}$ package. Software Impacts, 4, 100016.

8. Tran T, Ho MT, Pham TH, Nguyen MH, Nguyen PKL, Vuong TT, Nguyen TH, Nguyen TD, Nguyen TL, Khuc Q, La VP, Vuong QH. (2020). How Digital Natives Learn and Thrive in the Digital Age: Evidence from an Emerging Economy. Sustainability, 12(9), 3819.

9. Vuong QH, La VP, Nguyen MH, Ho MT, Tran T, Ho MT. (2020). Bayesian analysis for social data: A step-by-step protocol and interpretation. MethodsX, 7:100924.

10. Vuong TT, Ho MT, Nguyen MH, Nguyen TTH, Nguyen TD, Nguyen TL, Luong AP, Vuong QH. (2020). Adopting open access in the social sciences and humanities: Evidence from a developing nation. Heliyon, 6(7), e04522.

11. Ho MT, La VP, Nguyen MH, Pham TH, Vuong TT, Vuong HM, Pham HH, Hoang $A D$, Vuong QH. (2020). An analytical view on STEM education and outcomes: Examples of the social gap and gender disparity in Vietnam. Children and Youth Services Review, 119, 105650.

12. Vuong $\mathrm{QH}$, Bui AT, La VP, Nguyen $\mathrm{MH}$, Pham HH, Pham $\mathrm{TH}$, TVu TH, Vuong $T$, Ho MT. (2021). Mirror, mirror on the wall: Is economics the fairest of them all? An investigation into the social sciences and humanities in Vietnam. Research Evaluation, 30(1), 57-71. 
13. Vuong QH, Ho MT, Nguyen MH, Pham TH, Vuong TT, Khuc QV, Ho HA, La VP. (2021). On the environment-destructive probabilistic trends: a perceptual and behavioral study on video game players. Technology in Society, 65, 101530.

14. Vuong QH, Bui AT, Ho MT, Pham TH, Vu TH, Pham HH, Hoang AD, Ho MT, La VP. (2021). Top economics universities and research institutions in Vietnam: Evidence from the SSHPA dataset. Heliyon, 7(2), e06273.

15. Nguyen MH, Le TT, Nguyen HKT, Ho MT, Nguyen HTT, Vuong QH. (2021). Alice in Suicideland: Exploring the Suicidal Ideation Mechanism through the Sense of Connectedness and Help-Seeking Behaviors. International Journal of Environmental Research and Public Health, 18 (7), 3681.

16. Vuong QH, Nguyen TTH, Ho MT, Nguyen MH. (2021). Adopting open access in an emerging country: Is gender inequality a barrier in Humanities and Social Sciences?. Learned Publishing, 34(4), 487-498.

17. Vuong QH, Nguyen MH, Le TT. (2021). Home scholarly culture, book selection reason, and academic performance: Pathways to book reading interest among secondary school students. European Journal of Investigation in Health, Psychology and Education, 11(2), 468-495.

18. Vuong QH, La VP, Ho MT, Pham TH, Vuong TT, Vuong HM, Nguyen MH. (2021). A data collection on secondary school students' STEM performance and reading practices in an emerging country. Data Intelligence, 3(2), 336-356.

19. Hoàng VQ, Phương LV, Trung T, Hoàng NM, Toàn HM. (2021). Bản hòa tâu dũ liệu xã hội. Nxb Khoa học Xã hội, Hà Nội.

20. Vuong QH, Nguyen MH, Le TT. (2021). A mindsponge-based investigation into the psycho-religious mechanism behind suicide attacks. Warsaw, Poland: De Gruyter / Sciendo.

21. Vuong QH, La VP, Nguyen MH, Nguyen THT, Ho MT. (2021). Good budget or good care: The dilemma of social health insurance in Vietnam. SAGE Open Medicine, 9, 1-16.

22. Nguyen HTT, Nguyen MH, Ho MT, Le TT, Vuong QH. (2021). Open Access Publishing Probabilities Based on Gender and Authorship Structures in Vietnam. Publications, 9(4), 45.

23. Vuong QH, Ho MT, La VP, Le TT, Nguyen THT, Nguyen MH. (2021). A multinational dataset of game players' behaviors in a virtual world and environmental perceptions. Data Intelligence, 3(4), 606-630.

24. Mantello P, Ho MT, Nguyen MH, Vuong QH. (2021). Bosses without a heart: Socio-demographic and cross-cultural determinants of attitude toward emotional AI in the workplace. $A I$ \& Society, 36.

25. Vuong QH, La VP, Nguyen HTT, Vuong TT, Vuong HM, Ho MT. (2021). Impacts of parents and reading promotion on creating a reading culture: Evidence from a developing context. Children and Youth Services Review, 131, 106311. 
26. Nguyen MH, Vuong QH. (2022). Evaluation of the Aichi Biodiversity Targets: The international collaboration trilemma in interdisciplinary research. Pacific Conservation Biology, 28.

27. Nguyen MH, Nguyen HTH, Toan HM, Le TT, Vuong QH. (2022). The roles of female involvement and risk aversion in open access publishing patterns in Vietnamese social sciences and humanities. Journal of Data and Information Science, 7(1), 76-96.

28. Khuc VQ, Nguyen T, Nguyen T, Pham L, Le DT, Ho HH, Truong TB, Tran QK. (2021). Young Adults' Intentions and Rationales for COVID-19 Vaccination Participation: Evidence from a Student Survey in Ho Chi Minh City, Vietnam. Vaccines, 9(7), 794.

29. Nguyen MH. (2021). Multifaceted Interactions between Urban Humans and Biodiversity-related Concepts: A Developing-country Data Set. Data Intelligence, 3(4), 578-605. 